\title{
PEMBUATAN BUKU DIGITAL PADA EKOWISATA MANGROVE WONOREJO SURABAYA
}

\author{
Vivine Nurcahyawati ${ }^{1}$,Erwin Sutomo ${ }^{2}$, M. J. Dewiyani Sunarto ${ }^{3}$ \\ 1Institut Bisnis dan Informatika Stikom Surabaya. E-mail : vivine@stikom.edu \\ 2Institut Bisnis dan Informatika Stikom Surabaya. E-mail : sutomo@stikom.edu \\ ${ }^{3}$ Institut Bisnis dan Informatika Stikom Surabaya. E-mail : dewiyani@stikom.edu
}

\begin{abstract}
Mangrove forests is one of the potential resources of some coastal areas of Indonesia that have ecological functions, social and economic functions, and physical functions. Good management will make the mangrove forest area as an attractive tourist area with many visitors. To make the forest area of Mangrove become an attractive tourist spot, it is needed an information media that can provide information clearly and completely. As an effort to develop the potential of ecotourism in Surabaya, Surabaya city government has established a regional technical implementation unit that is Mangrove Information Center (MIC). To help MIC, it has been made an information media that can be widely accessed by visitors with easy and interesting. The media is a digital information book about the area of Mangrove tourism, which can be accessed widely.
\end{abstract}

Keywords: Mangrove, Digital Book, Information Media

\begin{abstract}
ABSTRAK
Hutan mangrove adalah salah satu sumber daya yang berpotensi di area pesisir Indonesia yang memiliki fungsi ekologis, fungsi sosial dan ekonomi, serta fungsi fisik. Pengelolaan yang baik akan membuat wilayah hutan mangrove menjadi area pariwisata yang diminati banyak pengunjung. Agar hutan Mangrove dapat menjadi kawasan tempat wisata yang menarik, maka diperlukan sebuah media informasi yang dapat menyediakan informasi secara jelas dan lengkap. Sebagai salah satu usaha pengembangan potensi lokasi ekowisata di Surabaya., pemerintah kota Surabaya telah membentuk unit pelaksana teknis daerah (UPTD) Mangrove Information Center (MIC). Untuk mengatasi permasalahan dari MIC di atas, maka telah dibuat sebuah media informasi yang dapat diakses secara luas oleh pengunjung dengan mudah dan menarik. Media tersebut adalah terbentuknya buku informasi berbentuk digital tentang kawasan wisata Mangrove, yang dapat diakses secara luas.
\end{abstract}

Kata Kunci: Mangrove, Buku Digital, Media Informasi

\section{PENDAHULUAN}

Sebagai upaya mengembangkan potensi ekowisata di kota Surabaya, pemerintah kota Surabaya telah membentuk unit pelaksana teknis daerah (UPTD) Mangrove Information Center (MIC). Tujuan pembentukan MIC untuk lebih mengenalkan ekowisata Mangrove. MIC diletakkan di daerah Wonorejo, karena merupakan lokasi yang paling representatif untuk pengembangan tanaman mangrove. Hutan atau Ekowisata Mangrove Wonorejo berada di Jl. Raya Wonorejo No. 1, Rungkut, Surabaya. Lokasi tersebut dapat dicapai dengan sangat mudah dari beberapa titik seperti dari Bandara Internasional 
Juanda, jarak dari bandara sekitar $17 \mathrm{Km}$ yang dapat ditempuh dalam waktu kurang lebih 1 jam. Luas area hutan mangrove yang dikelola MIC kurang lebih 200 hektar. Di dalamnya juga terdapat kurang lebih 30 spesies binatang yang termasuk dilindungi.

MIC memiliki fokus untuk mengembangkan ekowisata mangrove salah satunya dengan pembibitan tanaman mangrove dan pengembangan produk berbahan mangrove. Selain itu MIC juga berperan memberikan informasi secara luas kepada masyarakat tentang tanaman mangrove. Berdasarkan hasil wawancara dengan pengelola MIC, setidaknya setiap hari rata-rata ada lebih dari 50 orang pengunjung. Jumlah pengunjung bisa meningkat tajam pada hari sabtu dan minggu yang dapat mencapai 1000 pengunjung. Informasi tentang tanaman mangrove masih sangat terbatas dalam hal bentuk dan jumlahnya, sehingga MIC mengalami kesulitan dalam memberikan informasi kepada pengunjung secara lebih luas.

Selain pengunjung yang bertujuan berwisata, terdapat pengunjung yang datang untuk mendapatkan informasi tentang tanaman mangrove. Beberapa diantaranya datang secara berkelompok. Berdasarkan data di MIC Wonorejo, jumlah pengunjung yang bertujuan mendapatkan informasi dan edukasi tentang tanaman mangrove, mencapai 5 10 rombongan per bulan. Informasi yang ada saat ini masih berbentuk buku dengan jumlah terbatas. Tidak seluruh pengunjung bisa mengakses informasi melalui buku tersebut. Keterbatasan tersebut membuat MIC mencoba mencari solusi untuk memperbanyak akses ke informasi yang dimiliki. Prioritas solusi yang dibutuhkan saat ini adalah ada sebuah media informasi yang dapat didistribusikan secara luas kepada masyarakat. Media tersebut berisi informasi secara menyeluruh tentang tanaman maupun ekowisata mangrove.

Solusi yang ditawarkan untuk permasalahan mitra adalah membuat media informasi tentang tanaman dan ekowisata mangrove berbentuk digital. Media digital tersebut berbentuk buku digital yang berbentuk flipbook. Bentuk flipbook bisa disebarkan secara luas melalui website maupun video.

\section{METODE PELAKSANAAN}

Ekowisata Mangrove Wonorejo adalah salah satu potensi pariwisata Kota Surabaya yang dikembangkan oleh pemerintah kota Surabaya. Ekowisata Mengrove Wonorejo berada dibawah kordinasi Unit Pelayanan Teknis Daerah Mangrove Information Center. Kawasan Wonorejo merupakan lahan yang representatif untuk pemberdayaan mangrove (Wijayanti, 2007). Ekowisata mangrove ini dibuat sebagai upaya dari pemerintahan kota Surabaya untuk meningkatkan penggunaan lahan konservasi dan wilayah ini terbatas peruntukannya (Arisandi, 2001) Ekowisata Mangrove Wonorejo juga digunakan oleh pemerintahan kota surabaya untuk meningkatkan kesadaran masyarakat akan pentingnya Mangrove dan peningkatan kesuburan Mangrove di Surabaya,

Fokus yang dikembangkan oleh Ekowisata Mangrove salah satunya adalah dengan pembibitan tanaman mangrove dan pengembangan produk berbahan mangrove (Arisandi, 2004). Ekowisata Mangrove Wonorejo memiliki pengelolaan mangrove mulai dari bibit hingga perawatan, sehingga banyak jenis spesies Mangrove yang ditanam di 
area tersebut. Permasalahan yang dialami oleh Ekowisata Mangrove saat ini adalah tidak adanya media atau mekanisme pelayanan edukatif pada masyarakat, sehingga potensi hutan Mangrove ini menjadi tidak tersampaikan dengan baik.

Berdasarkan latar belakang diatas, maka transfer IPTEK yang akan dilakukan pada pengabdian masyarakat ini adalah dengan membuat sebuah sarana edukatif berupa Buku Digital yang diharapkan dapat membantu pihak Ekowisata Mangrove dalam menyampaikan informasi tentang potensi Mangrove. Pembuatan buku digital dengan menggunakan aplikasi komputer (perangkat lunak) akan berisi beberapa hal seperti: Peta lokasi Ekowisata Mangrove Wonorejo, Peta konservasi Mangrove, Pengetahuan tentang jenis spesies Mangrove.

Terdapat 3 tahap yang dilakukan untuk melakukan kegiatan pengabdian masyarakat ini, meliputi: identifikasi kebutuhan mitra, pembuatan buku digital dan pelatihan penggunaan buku digitalnya. Langkah pertama yaitu identifikasi kebutuhan mitra. pada langkah ini yang dilakukan adalah mengidentifikasi kebutuhan mitra, yang meliputi: (1) mempelajari literatur-literatur terkait mangrove dan pengelolaannya sebelum bertemu dengan narasumber pada ekowisata mangrove wonorejo, (2) melakukan survey dan wawancara pada mitra, untuk mendetailkan kebutuhan yang menjadi permasalahan disana, (3) menyusun spesifikasi kebutuhan mitra berdasarkan hasil survey dan wawancara. Disini akan didetilkan tentang informasi apa saja yang harus ada dalam buku digital yang akan dibuat. (4) Menentukan perangkat lunak pendukung yang akan digunakan untuk membuat buku digital.

Langkah kedua adalah pembuatan buku digital. Setelah dihasilkan analisa kebutuhan mitra dan menentukan perangkat pendukung, maka langkah selanjutnya adalah membuat buku digitalnya. Kerangka isi buku perlu dibuat terlebih dahulu sebagai panduan penataan informasi-informasi yang akan ditampilkan. Setelah buku digital selesai dibuat maka selanjutnya yang perlu dilakukan adalah melakukan ujicoba pada buku digital tersebut guna memastikan apakah sudah dapat digunakan sesuai yang telah direncanakan dan informasi-informasinya telah benar sesuai dengan sumber yang digunakan. Selanjutnya langkah terakhir yaitu pelatihan penggunaan buku digital. Setelah buku digital selesai dibuat, tahap selanjutnya adalah melakukan pelatihan terhadap seluruh pengguna pada mitra agar bisa menggunakan buku digital ini dengan baik dan lancar.

\section{HASIL DAN PEMBAHASAN Identifikasi Kebutuhan Mitra}

Setelah berbincang dengan person di MIC, maka didapatkan gambaran umum isi dari buku digital adalah sebagai berikut:

Tabel 1 Gambaran Umum Isi Buku Digital

\begin{tabular}{|c|c|c|}
\hline $\begin{array}{c}\text { Peta Lokasi (Lokasi MIC, } \\
\text { Fasilitas MIC) }\end{array}$ & Peta Konservasi & Pengetahuan tentang Mangrove \\
\hline 1. Pengantar tentang MIC & $\begin{array}{lr}\text { 1. Peta Lokasi / sebaran } \\
\text { tanaman } & \text { mangrove } \\
\text { (ditampilkan } & \text { tentang }\end{array}$ & $\begin{array}{l}\text { 1. Penjelasan tentang tanaman } \\
\text { mangrove per jenis ( informasi } \\
\text { detail jenis/spesies mangrove) }\end{array}$ \\
\hline
\end{tabular}




\begin{tabular}{llll}
\hline & $\begin{array}{l}\text { lokasi tabam tiap jenis } \\
\text { mangrove) }\end{array}$ & $\begin{array}{l}\rightarrow \text { foto dan informasi terkait dari } \\
\text { setiap jenis tanaman }\end{array}$ \\
\hline 2. Fasilitas dan Lokasi MIC & $\begin{array}{l}\text { 2. Nama dan foto setiap } \\
\text { jenis tanaman Mangrove }\end{array}$ \\
\hline $\begin{array}{l}\text { 3. Peta lokasi/ sebaran } \\
\text { tanaman mangrove }\end{array}$ & $\begin{array}{l}\text { 3. Lokasi (nama dan foto), } \\
\text { serta peta lokasi }\end{array}$ \\
\hline $\begin{array}{l}\text { 4. Menjelaskan tentang } \\
\text { tanama mangrove per jenis : }\end{array}$ & $\begin{array}{l}\text { 4. Foto dan informasi } \\
\text { ditampilan tentang informasi } \\
\text { detil jenis dan setiap jenis tanaman } \\
\text { mangrove spesies }\end{array}$ & \\
\hline
\end{tabular}

\section{Hasil Pengambilan Foto}

Setelah dilakukan pengambilan foto sebanyak 2 kali pada tanggal 13 Juli 2016 dan 28 Juli 2016, maka didapatkan foto tanaman dan lokasi MIC, dengan contohnya seperti nampak pada gambar di bawah ini :

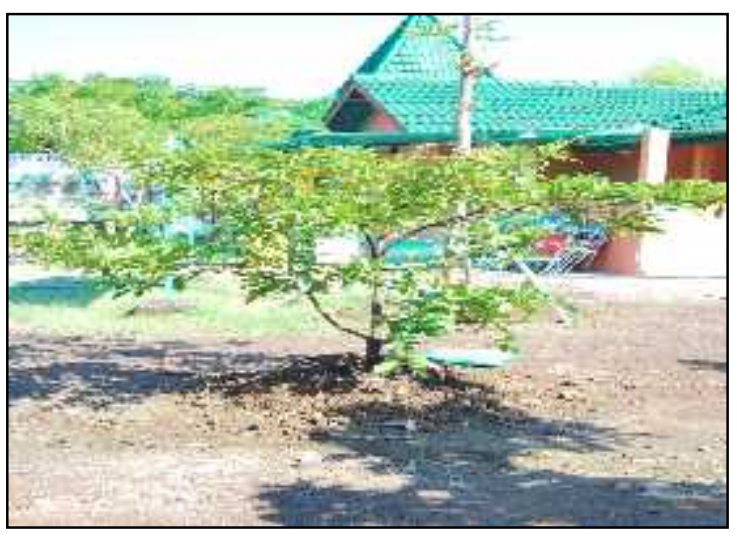

Gambar 1 Tanaman Avicennia Alba Blume

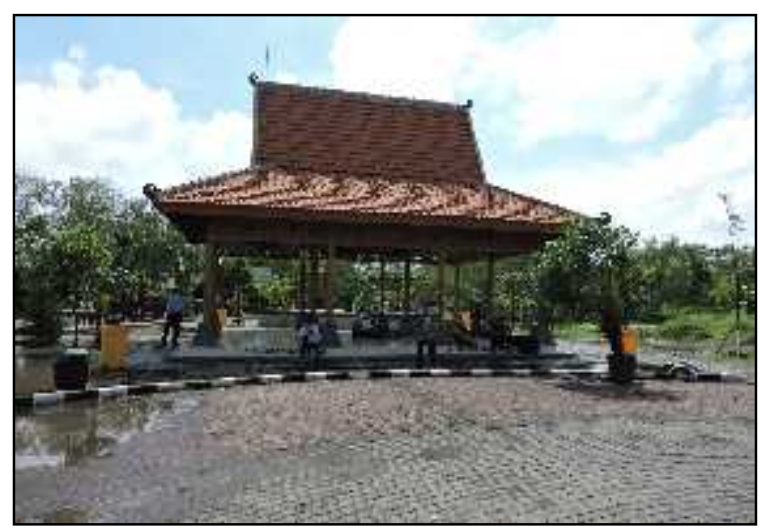

Gambar 2 Foto depan MIC

\section{Penentuan Aplikasi Pembuat Flipbook}

Setelah menjajaki beberapa aplikasi pembuat flipbook, maka ditetapkan aplikasi yang akan digunakan untuk membuat buku digital ini adalah Camtasia Studio.

\section{Tampilan Buku Digital}

Setelah melalui tahapan-tahapan yang ada maka dapat dihasilkan sebuah buku digital yang berisi tentang kebutuhan dari mitra. Beberapa contoh hasil dapat dilihat pada gambar-gambar berikut ini. Pada halaman pertama terdapat informasi tentang MIC sebagai mitra pengguna dan terdapat logo Stikom Surabaya dan Dinas Pertanian, seperti terlihat pada gambar 3. Diikuti oleh penjelasan awal tentang jenis-jenis Mangrove seperti pada gambar 4 . 


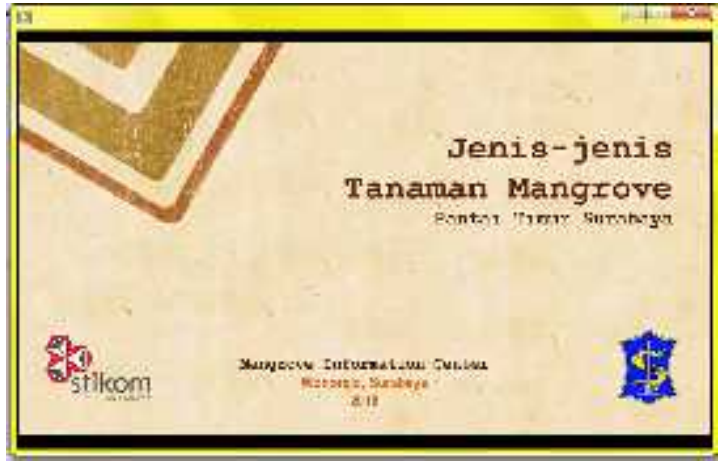

Gambar 3. Halaman Pembuka Buku Digital Mangrove

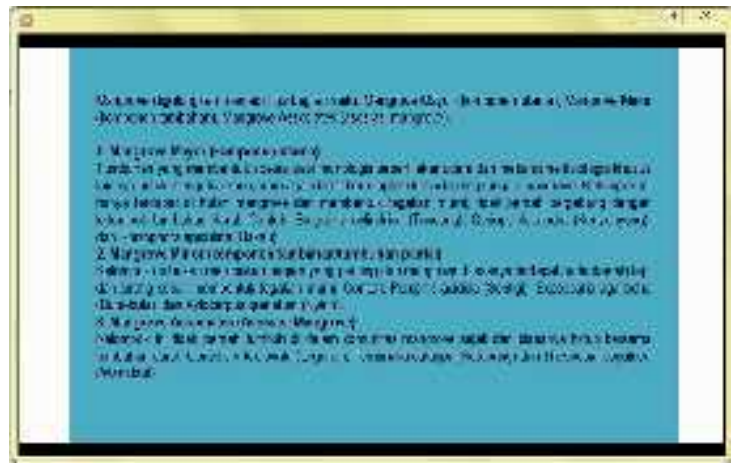

Gambar 4. Penjelasan Awal Jenis-Jenis Mangrove

Kawasan wisata mangrove tidak hanya berisi konservasi tanaman mangrove, beberapa fasilitas lain juga disediakan antara lain gazebo, area parkir, rumah buku, tempat makan, wisata pantai dan beberapa fasilitas yang lain. Fasilitas diupayakan menjadi lebih lengkap dengan tujuan untuk meningkatkan pelayan dari pihak MIC. Beberapa contoh fasilitas dapat terlihat pada gambar 5 sampai gambar 8 .

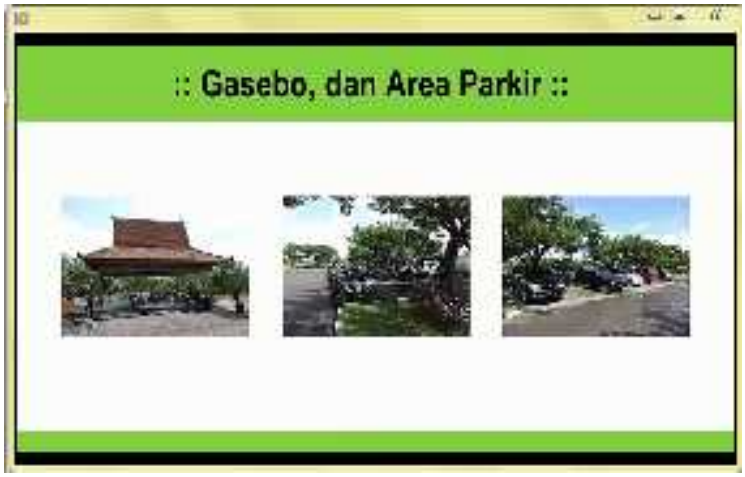

Gambar 5. Gasebo dan Area Parkir

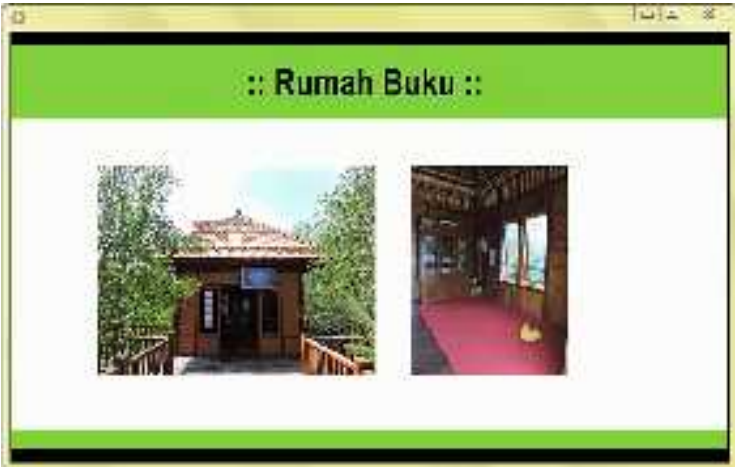

Gambar 6. Rumah Buku

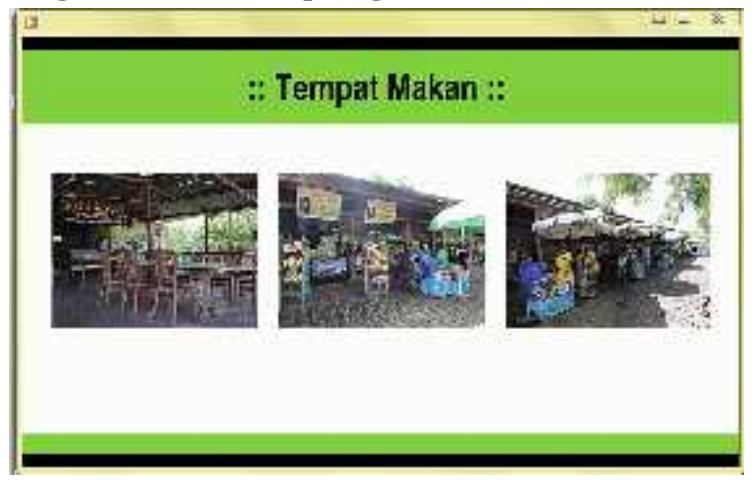

Gambar 7. Tempat Makan

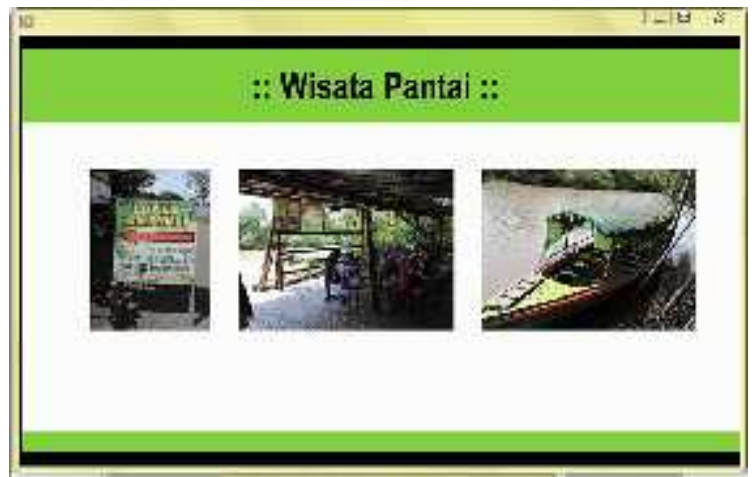

Gambar 8. Wisata Pantai

Pada halaman berikutnya dijelaskan tentang sebaran tanaman mangrove. Terlihat pada sebaran areanya, ada mangrove yang tumbuh pada area khusus namun ada juga yang tumbuh dibanyak area. Gambar 9 sampai gambar 12 menunjukkan sebaran tanaman mangrove. 


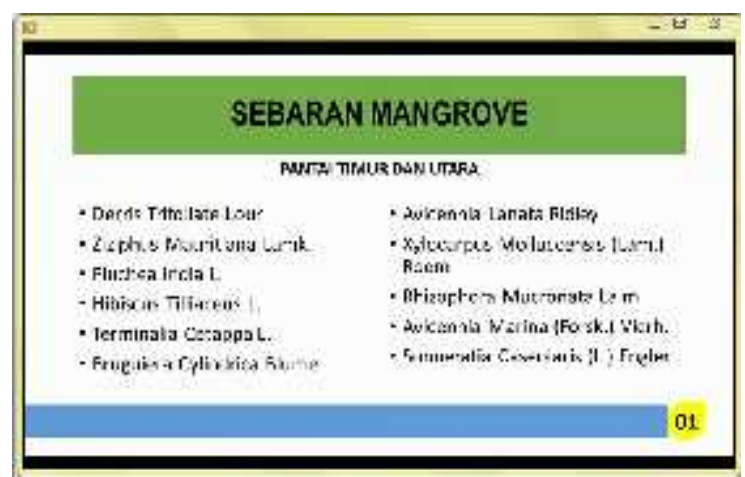

Gambar 9. Pantai Timur dan Utara

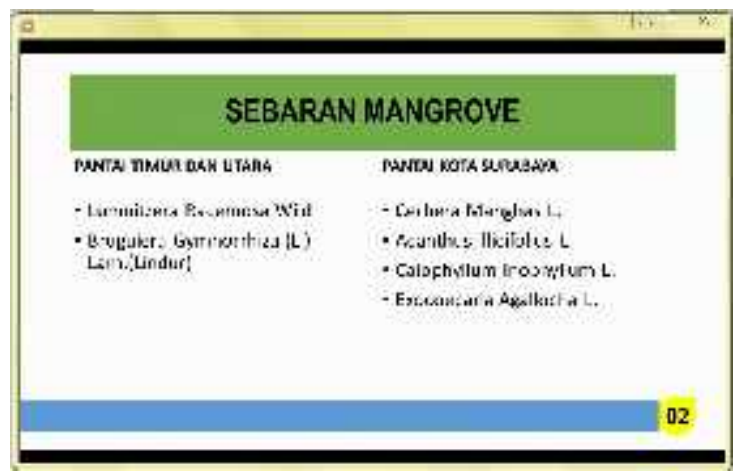

Gambar 11. Pantai Kota Surabaya

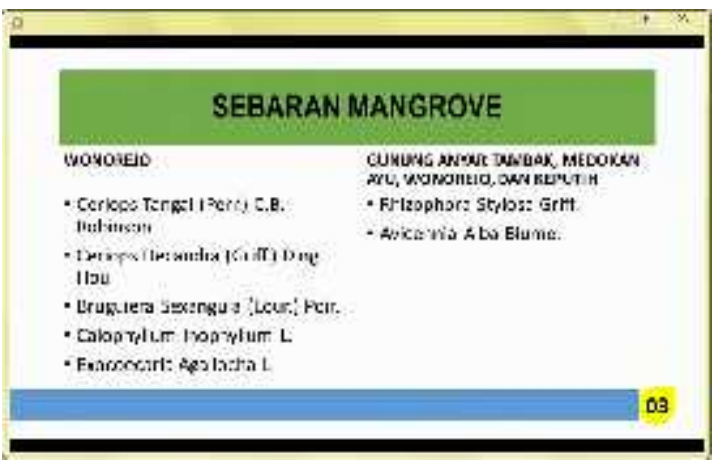

Gambar 10. Wonorejo dan Area-area lainnya

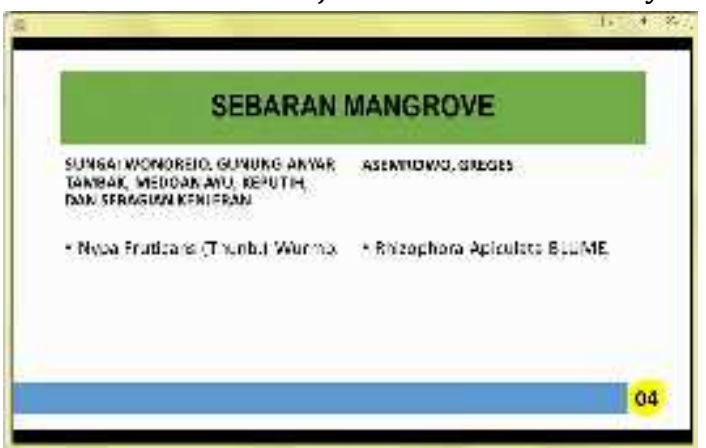

Gambar 12. Sungai Wonorejo dan Area-area lainnya

Isi utama dari buku digital ini adalah terkait macam-macam tanaman mangrove beserta penjelasan tentang hal umum yang perlu diketahui tentang jenis tanaman mangrove tersebut, penjelasan tentang bunga, buah dan daunnya, tentang habitat, penyebaran dan manfaat yang bisa diambil dari jenis mangrove tersebut. Penjelasan diawali dari tipe Mangrove Mayor, Mangrove Minor dan terakhir adalah untuk kelompok Mangrove Asosiasi. Contoh penyajian pada buku digital dapat terlihat pada gambar 13 sampai gambar 20.

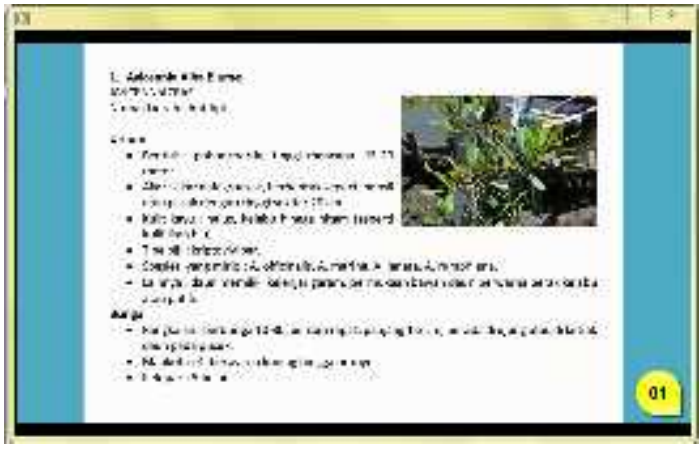

Gambar 13. Contoh Mangrove Mayor (1)

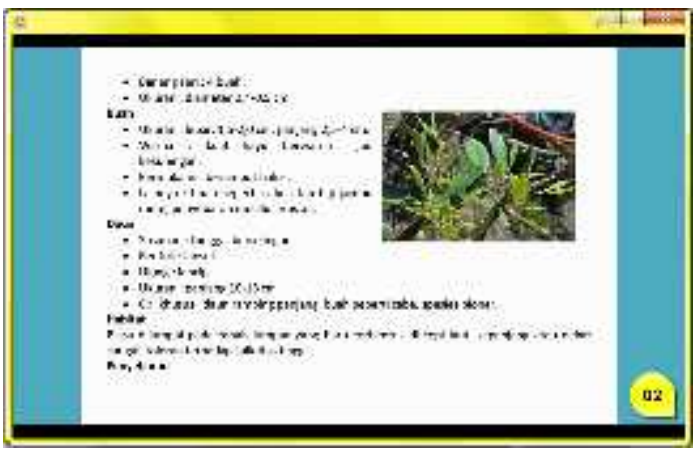

Gambar 14. Contoh Mangrove Mayor (2) 


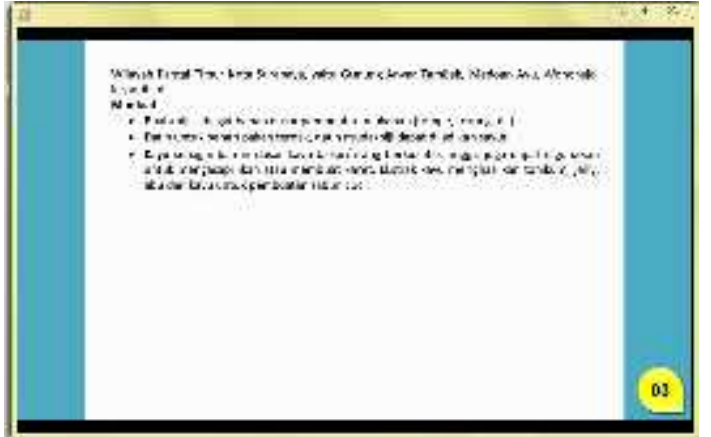

Gambar 15. Contoh Mangrove Mayor (3)

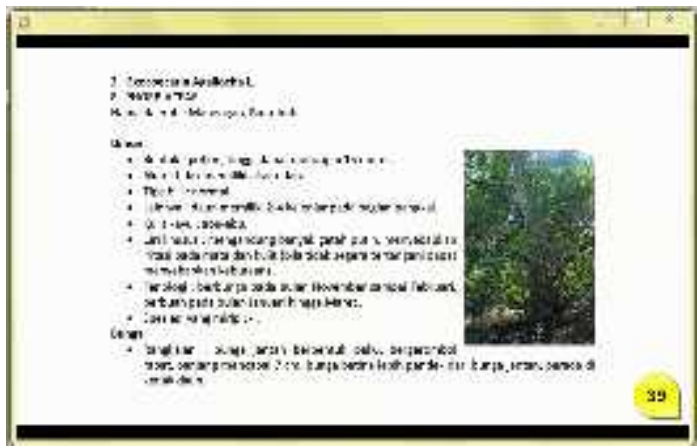

Gambar 16. Contoh Mangrove Minor (1)

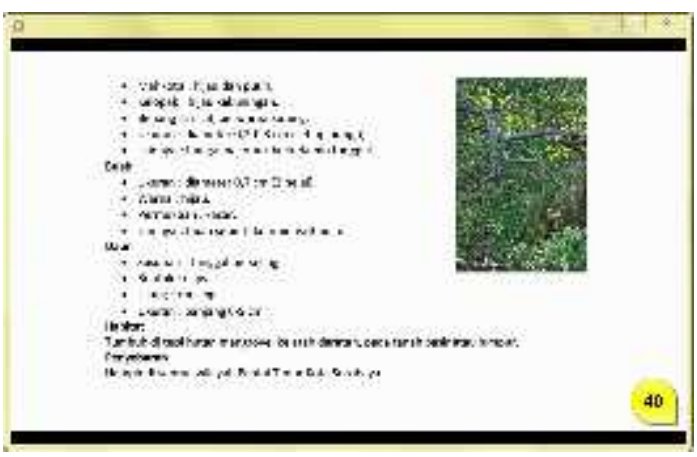

Gambar 17. Contoh Mangrove Minor (2)

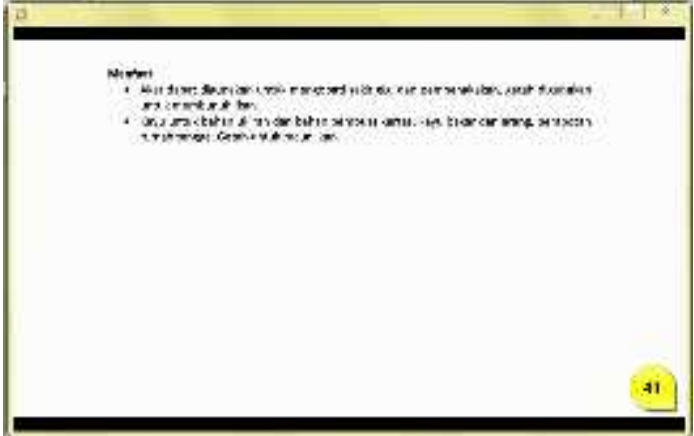

Gambar 18. Contoh Mangrove Minor (3)

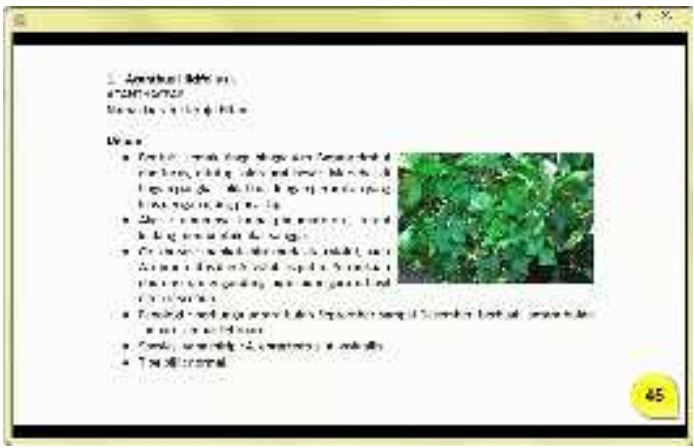

Gambar 19. Contoh Mangrove Asosiasi (1)

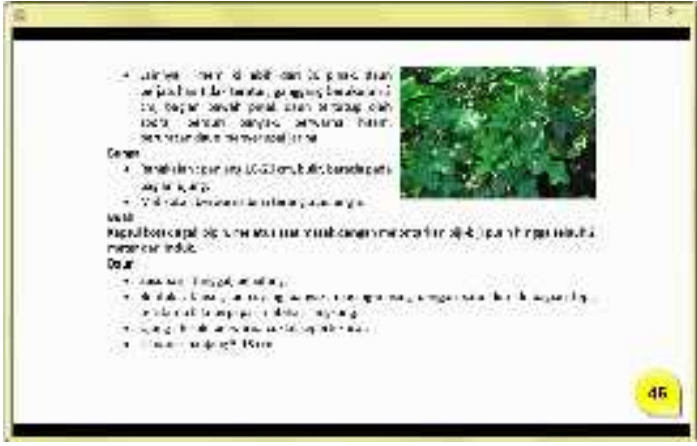

Gambar 20. Contoh Mangrove Asosiasi (2)

\section{Pelatihan Penggunaan Buku Digital}

Sebelum nantinya buku digital tentang tanaman mangrove ini dapat digunakan untuk membantu pihak MIC, kami harus memastikan bahwa isinya sudah sesuai dengan kebutuhan MIC. Kami melakukan pertemuan dengan perwalikan dari pihak MIC untuk menunjukkan hasil aktifitas kami. Pertemuan dilaksanakan pada hari Kamis, 26 Januari 2017 pukul 09:00 - 12:00 WIB. Koordinator MIC yang hadir pada pertemuan tersebut menyampaikan bahwa pihak MIC sangat mengharapkan ada bantuan-bantuan lain untuk lebih memperluas informasi tentang konservasi mangrove Wonorejo ini. 


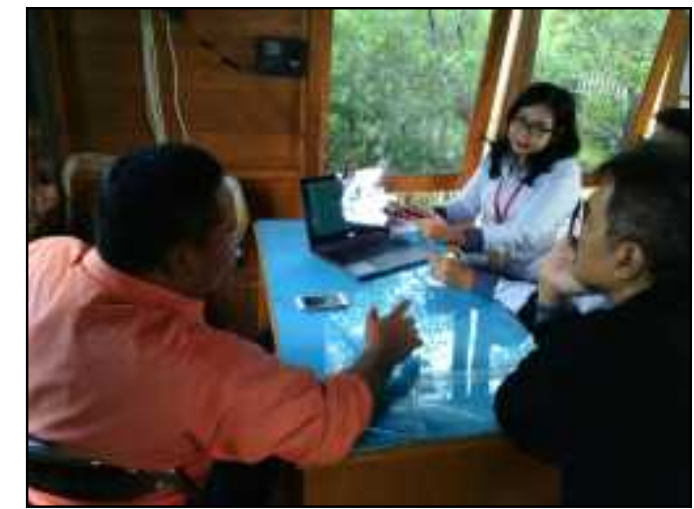

Gambar 21. Penjelasan Tentang Buku Digital kepada Koordinator MIC (1)

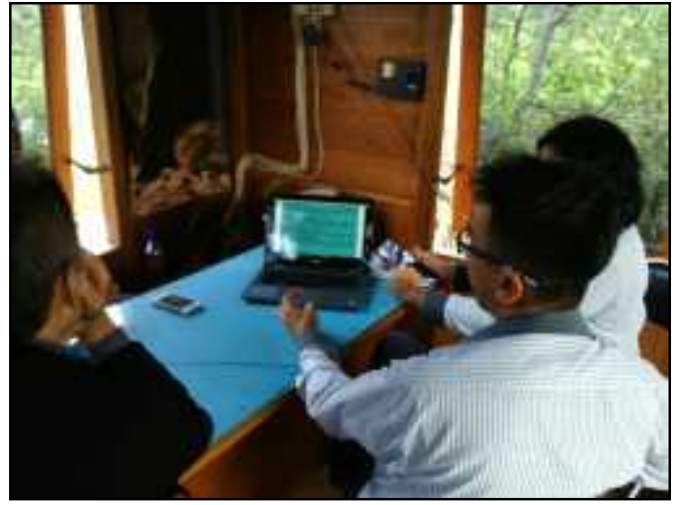

Gambar 22. Penjelasan Tentang Buku Digital kepada Koordinator MIC (2)

\section{SIMPULAN}

Setelah melalui tahapan-tahapan yang telah direncakan, pembuatan buku digital tentang jenis-jenis tanaman mangrove dapat diselesaikan dengan baik. Buku digital berisi tentang penjelasan peta lokasi ekowisata mangrove Wonorejo, peta konservasi mangrove dan pengetahuan tentang jenis spesies mangrove. Buku digital akan digunakan pihak MIC untuk membantu aktifitas memberikan informasi kepada pengunjung MIC tentang jenis-jenis mangrove.

\section{DAFTAR RUJUKAN}

Arisandi, P. (2001). Mangrove Jawa Timur Hutan Pantai yang Terlupakan. Gresik: Ecological Observation and Wetlands Conservation (ECOTON).

Arisandi, P. (2004). Mangrove Pantai Timur Surabaya Terancam Punah. Surabaya: Ecoton.

Wijayanti, T. (2007). Konservasi Hutan Mangrove sebagai Wisata Pendidikan. Surabaya: Tugas Akhir Mahasiswa Teknik Lingkungan Universitas Pembangunan Nasional "Veteran" Jawa Timur. 